\title{
Little Owl's (Athene noctua) vertebrate food composition during breeding season with high frog dominance in grasslands
}

\author{
Dániel HÁmori ${ }^{1,2 *}$, Dániel WINKLER ${ }^{1} \&$ Tamás CSERKÉSZ ${ }^{3}$
}

\author{
Received: November 11, 2018 -Revised: November 30, 2018 -Accepted: December 01, 2018
}

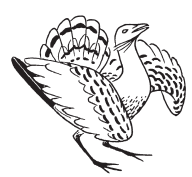

Hámori, D., Winkler, D. \& Cserkész, T. 2018. Little Owl's (Athene noctua) vertebrate food composition in breeding season with high frog dominance in grasslands. - Ornis Hungarica 27(1): 44-61. DOI: 10.2478/orhu-2019-0003

Abstract The aim of our study was to investigate the feeding of the Little Owl (Athene noctua) during the breeding period in three protected sites (Upper Kiskunság Puszta, Upper Kiskunság Lakes, Peszéradacs Meadows) in an extensively managed lowland plain area (Upper Kiskunság) of the Carpathian Basin. A further objective was to provide a detailed assessment of the vertebrate prey spectrum and dominance structure based on the analyses of pellets. Little Owl pellets were collected in September 2015 and 2016 from 20 artificial nest boxes in which successful breeding occurred in both years. Mean pellet number was calculated per individuals. Distribution of individual number and biomass of vertebrate prey taxa were also examined. The number of collected and dissected owl pellets was 2,094 in 2015 and 2,024 in 2016, respectively. The average rate of pellet regurgitation was 25.57 pellets/ind. in 2015, and 27.74 pellets/ind. in 2016. From the 40 samples ( 4,118 owl pellets) a total of 2,017 vertebrate preys were determined. Cumulative species richness was 21, including 12 mammalian, 1 amphibian, 4 reptile and 4 bird species. Mammals were dominant in the food (average 50.83\%), and the consumption of amphibians was similar (48.06\%). The consumption of birds and reptiles was not significant. Amphibians were represented by a single species, the Common Spadefoot (Pelobates fuscus) in remarkably high proportions among the prey items, followed by the Common Vole (Microtus arvalis) by approx. 37\% proportion. The high proportion of the latter two species was also clearly reflected in the biomass amounts. Among the birds, the Starling (Sturnus vulgaris) proved to be the most commonly predated species apart from other species closely related to farmland habitats (Motacilla alba, M. flava, Passer montanus).

Keywords: nutrition, owl pellet analysis, Kiskunság, grassland, Strigidae, Amphibia

Összefoglalás A kutatás célja a kuvik (Athene noctua) költési időszakra vonatkozó táplálkozásának vizsgálata volt a Felső-Kiskunság három védett területegységén (Felső-Kiskunsági Puszta, Felső-Kiskunsági Tavak, Peszéradacsi Rétek). Célunk volt a kuvik gerinces zsákmányállataira kiterjedő részletes, nagyobb mintaszámú vizsgálata, e közösség tekintetében a faj táplálkozási szokásainak és alkalmazkodási képességének feltárása. 2015-ben és 2016ban célzottan került sor köpetgyüjtésre, a kirepülést követően (szeptember) azon odúkból, amelyekben sikeres költés zajlott mindkét évben. Megállapítottuk az egy egyedre eső átlagos köpetszámot, valamint területi és gyüjtési év elkülönítésben vizsgáltuk a gerinces zsákmányfajok egyedszám és biomassza-tömeg szerinti megoszlását. A meghatározott/gyüjtött köpetszám 2015-ben 2094, 2016-ban 2024 volt. Az odúkban lezajlott köpetelések egy egyedre vonatkoztatott száma átlagosan 25,57 köpet/egyed volt 2015-ben, 27,74 köpet/egyed 2016-ban. A gyüjtött 40 mintában (4118 köpet) összesen 2017 gerinces zsákmányegyedet határoztunk meg. A mintákban azonosított fajok száma a két évre összességében 21 volt, amelyből 12 emlős-, 1 kétéltü-, 4 hüllö- és 4 madárfaj. A kuvikok az emlösöket zsákmányolták elsődlegesen (átlag 50,83\%), és ehhez hasonló mértékủ volt a kétéltűek fogyasztása is (átlag 48,06\%). A madarak és a hüllők fogyasztása nem volt jelentős. A kétéltủeket egyetlen faj, a barna ásóbéka (Pelobates fuscus) képviselte, amely mennyisége és aránya igen figyelemre méltó volt (átlagosan 41,68\%). A második meghatározó táplálékforrás a területen a mezei pocok (Microtus arvalis) volt 37\% részaránnyal. Előbbi két domináns faj magas egyedszám szerinti részaránya a biomassza-tömeg szerinti értékekben is egyértelműen tükröződött. A madarak közül a seregély (Sturnus vulgaris) bizonyult a leggyakrabban zsákmányolt fajnak más mezőgazdasági élőhelyekhez szorosan kötődő énekesmadarak (Motacilla alba, M. flava, Passer montanus) mellett. 


\footnotetext{
${ }^{1}$ University of Sopron, Institute of Wildlife Management and Vertebrate Zoology, 9400 Sopron, Bajcsy-Zsilinszky utca 4., Hungary

${ }^{2}$ Hungarian Little Owl Protecting Public Benefit Association, 1045 Budapest, Virág utca 11. X./58., Hungary

${ }^{3}$ Hungarian Natural History Museum, 1088 Budapest, Baross utca 13, Hungary

* corresponding author: hamoridanielkoe@gmail.com
}

\section{Introduction}

The population of the Little Owl (Athene noctua) has declined in many European countries, especially in the western areas (Cramp 1985, Mánez 1994, Heath et al. 2000, Génot \& Van Nieuwenhuyse 2002, Zmihorski et al. 2006, Šálek \& Schröpfer 2008, Van Nieuwenhuyse et al. 2008, Sunde et al. 2009, BirdLife International 2016). The number of breeding pairs in Hungary is estimated to be between 1,500 and 4,000 pairs, the population trend is unknown (Gorman 1995, Hadarics \& Zalai 2008, Śálek et al. 2013, BirdLife International 2016, Hámori 2017b). In certain regions of the Great Plain (e.g. Békés and Bács-Kiskun counties), the species has a significant population with increasing population trend observed in the past decade (Bozó \& Csathó 2017, Hámori et al. 2017b). As a consequence of their population decline, the conservation and research of the Little Owl have become important priorities in most European countries (e.g. Zerunian et al. 1982, Génot 1994, Angelici et al. 1997, Tomialojc \& Stawarczyk 2003, Zmihorski et al. 2006, Van Nieuwenhuyse et al. 2008). The ecological mechanisms responsible for these negative tendencies are less known. To date, many hypotheses have been raised as explanations, which include habitat-structural changes, habitat fragmentation, decline in feeding sites, and other ecological factors (Zerunian et al. 1982, Génot 1994, Angelici et al.1997, Schaub et al. 2006, Sunde et al. 2009, Zmihorski et al. 2009, Le Gouar et al. 2011). Most of the research related to Little Owls was carried out in Western Europe (e.g. Denmark, The Netherlands, Germany, Portugal, Spain); therefore the mechanisms described in these studies are not necessarily relevant to the Central and Eastern European populations (Van Nieuwenhuyse et al. 2008, Tryjanowski et al. 2011). The decreasing population trend of the Little Owl and related issues, such as detailed feeding biology, require further studies in Central and Eastern Europe. Agricultural intensification also contributed to the decline in food availability for many wild species (Newton 2004, Morris et al. 2005). This negative tendency can be observed also in the case of farmland bird species in Hungary (Szép \& Nagy 2006, Báldi \& Batáry 2011, Szép et al. 2012). Nevertheless, in addition to nesting-site availability, the trend of a given Little Owl population is closely related to the feeding possibilities and food availability (Génot \& Van Nieuwenhuyse 2002, Zmihorski et al. 2006, Thorup et al. 2010, Apolloni et al. 2018). In general, the effects of agricultural intensification may result in a decrease in the abundance of arthropods and small mammals (Morris 2000), which are the primary food sources for the Little Owl (Van Nieuwenhuyse et al. 2008). Furthermore, habitat transformations in agricultural areas may further reduce the availability of food to the owls (Apolloni et al. 2018). The Little Owl has various haunting techniques. As a polytypical species, and as the result of its large distribution area, the Little Owl catches a large number of different prey species (e.g. Mikkola 1983, Cramp 1985, Schönn et al. 1991, Angelici et al. 1997, Milchev \& Nikolay 2017). Primarily, small mammals and invertebrates dominate the Little Owl diet, but feed 
also on songbirds, amphibians, reptiles, and rarely fishes (Glutz von Blotzheim \& Bauer 1980, Cramp 1985, Schmidt 1998). The Little Owl is fundamentally generalist, so there is no clear correlation between the number of species and the number of pellets (Lanszki 2006, Van Nieuwenhuyse et al. 2008). According to the pellet analyses carried out in European and Middle Eastern countries, the Little Owl's diet consists mostly of insects, but its feeding habits may differ according to the habitat and geographical region (Herrera \& Hiraldo 1976, Cramp 1985, Gorzel \& Grzywaczewski 2003, Obuch \& Kristin 2004). Several studies on food composition and feeding habits have been carried out in the Mediterranean region, Western Europe and the Middle East (e.g. Obuch \& Kristin 2004, Alivizatos et al. 2005, Van Nieuwenhuyse et al. 2008, Kayahan \& Tabur 2016). Detailed studies on feeding biology are also essential in Central Europe to support nature conservation strategies. In Hungary, Little Owl feeding data are mostly pre-millenial or based on small number samples (Greschik 1911, 1924, Marián \& Schmidt 1968, Molnár 1984, Andrési \& Sódor 1986, Endes 1990), and only in some cases seasonal or fully processed (Lanszki 2006, Hámori et al. 2017a). In this respect, the Little Owl is one of the least studied owls in Hungary.

The main goal of our study was to investigate the vertebrate prey items of the Little Owl by analyzing a large number of pellets collected during the breeding period in an extensively managed lowland plain area of the Carpathian Basin; and thereby to explore the feeding habits and adaptation ability of this species. A further aim was to provide a detailed assessment of the vertebrate prey spectrum and dominance structure based on the analyses of pellets collected in the study sites.

\section{Material and methods}

\section{Study area}

The research was carried out in protected areas managed by the Kiskunság National Park in the north-western part of the Great Plain, in Pest and Bács-Kiskun counties (Map 1). The continental climate is dominant in the area. Average annual rainfall is moderate (540-670 $\mathrm{mm}$ ), warm summer and relatively cold winter (average annual temperature $13.3^{\circ} \mathrm{C}$ ) are the characteristics of this region. The average altitude is 84 meters. The landscape of the Kiskunság is uniform, established by the ancient Danube river. Large-scale agricultural intensification has begun since the turn of the $19^{\text {th }}$ century. Nowadays, more than $60 \%$ of the cultivated land is utilized by modern agricultural practices (Rakonczay 2001). A large part of the grasslands were maintained by grazing (sheep, cattle) and traditional grassland management. The elements of today's landscape are the canal systems, large plains, pastures, sand dunes, smaller salty lakes, bogs, reeds, sandy forests, as well as man-made arable land, orchards, vineyards, and the typical boonies of huge ecological importance for Little Owls. Traditional farming is still in existence and the typical farm life plays a significant role in preserving natural values (Voloscuk 1999). The Little Owl pellets were collected from the study sites Upper Kiskunság Puszta, Upper Kiskunság Lakes and Peszéradacs Meadows, a brief description of which is given below (Kollárik 1999, Voloscuk 1999, Rakonczay 2001). 


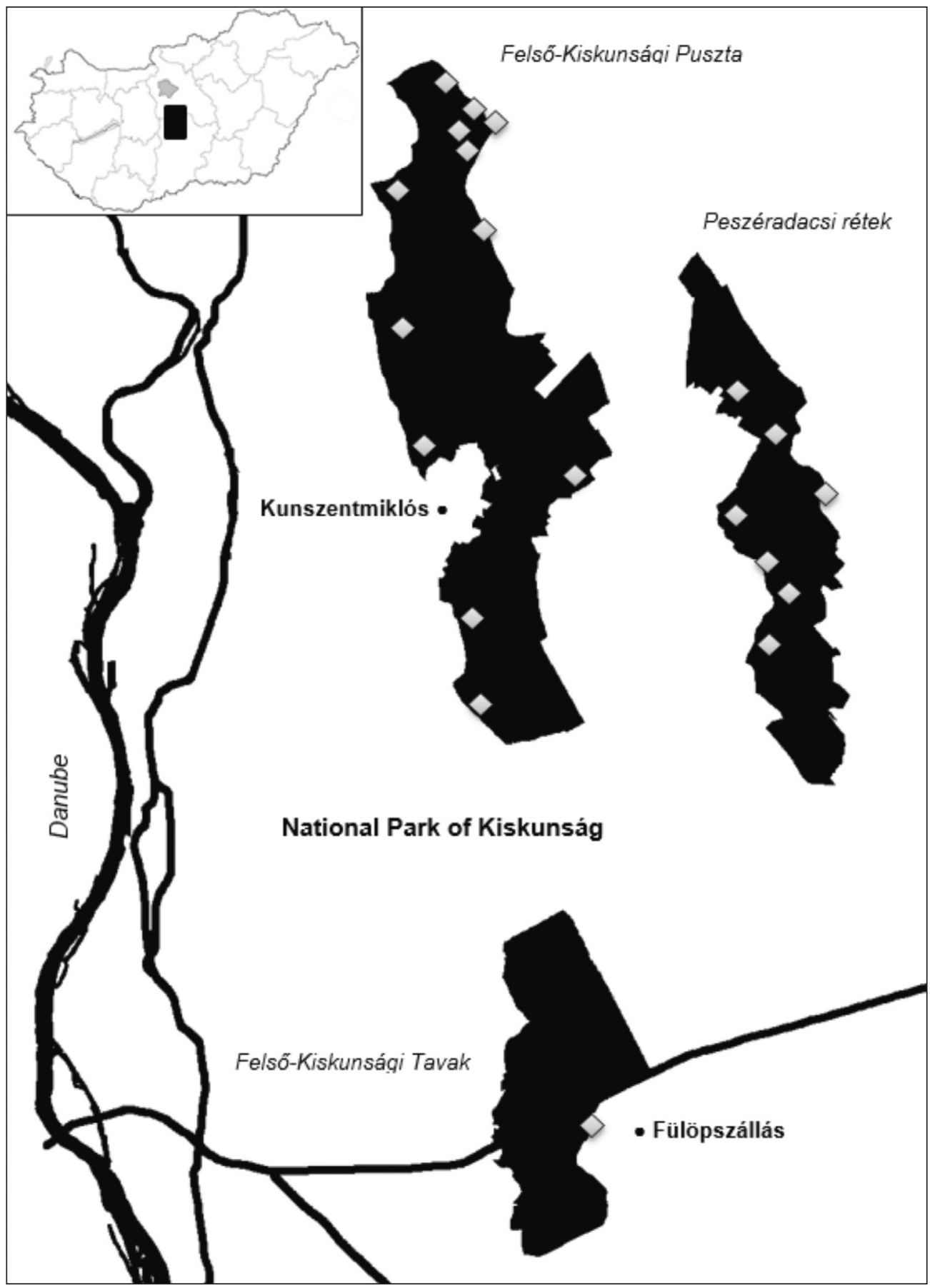

Map 1. Map of the study sites and sampling locations (artificial nest boxes)

1. térkép A gyűjtések alapjául szolgáló mesterséges kuvikodúk elhelyezkedése a kutatási területen 


\section{Upper Kiskunság Puszta (11,061 ha)}

The surrounding settlements of the Little Owl nesting places sampled are Apaj, Bugyi, Kiskunlacháza, Kunbábony and Kunszentmiklós. The hydrological conditions of the area have changed dramatically over the last century due to drainage works. The former wild waters were diverted and a channel system was constructed. As a consequence, salinization processes accelerated. Salty meadows and pastures are characterized by shallow lakes and other water bodies. The Solonchak-Solonetzic soils that characterize the area have resulted in the formation of salt-tolerant and halophilic vegetation. The vegetation of alkaline steppes has a mosaic-structure, which is due to the richness of the microrelief. The extensive area of permanent and temporary bodies provides favorable conditions for breeding and migratory birds as well as for amphibians. Traditional farming in this area is in decline. The few family sheep-farming are more and more replaced by dairy cattle farms. In the northern part of the area, organic farming is dominant, characterized primarily by the Hungarian gray cattle and water buffaloes. The sampling places of pellets are located in the close neighborhood of different farm buildings.

\section{Upper Kiskunság Lakes (3,905 ha)}

The adjacent settlement of Little Owl pellet sampling location is Fülöpszállás. The lakes in this area provide food supply (e.g. insect larvae, crustaceans) to the bird communities typical for halophytic habitats. A significant part of the area is covered by alder-narrow-leaved ash swamp forests. The pellet sampling was carried out next to an abandoned farming unit on the edge of the area.

\section{Peszéradacs Meadows (5,757 ha)}

Settlements neighbouring the Little Owl nesting places are Kunpeszér and Tatárszentgyörgy. In this sparsely populated countryside, grazing and traditional farming are characteristic. Water management has removed or transformed landscapes in most places. Among its varied habitats, wetlands, marshes, wet meadows and sandy grasslands and sandy forests are worth mentioning. The proportion of hay fields and wet meadows is high. The sampling places are mainly located in the immediate vicinity of the various farm buildings where usually sheep is housed.

\section{Pellet sampling and analysis}

Little Owl pellets were collected in September 2015 and 2016, in three different sites. The sampled material included all pellets found in the next boxes affected. Within the tree sites, mean distance between the sampling plots (nest boxes) was 2,660 m. Prior to sampling, we removed the old pellet remains from each nest box before the nesting period of the given year (15-31 March). The collected samples, therefore, contained food remains accumulated during the 6 months of the breeding season (spring and summer) by adults and their nestlings. The 
collected material therefore included part of the food remnants of the adult pair as well as total food remnants by the nestlings until their fledging from the nest. A significant part of the pellet material collected from the nest boxes were trampled by the young Little Owls. For the purpose of determining the approximate pellet number, any other extraneous material (e.g. chips) was first removed and the volume of the sample was measured. Based on the measurements of undamaged pellets $\left(\mathrm{N}=218\right.$; mean: $\left.5.62 \mathrm{~cm}^{3}\right)$ and on the basis of literature data (Sageder 1990, Gorzel \& Grzywaczewski 2003), the estimated pellet number of each sample was determined as the average of three measurements. The pellets were dried and processed by standard methods (Schmidt 1967, Raczyński \& Ruprecht 1974). The remains were analysed by using a stereo microscope under $15.75 \times$ or $25.2 \times$ magnification. Vertebrate and arthropod remains were selected separately from the pellet material for possible future determination. Small mammals were identified from skulls, mandibles and teeth based on the works of Schmidt (1967), Topál (1969), Móczár (1984), März (1987), Ujhelyi (1989), Diesener and Reicholf (1997). Birds were determined on the basis of skulls, bills, femurs and feathers (Brown et al. 1993, Kessler 2015), while amphibians and reptiles were identified by the lower arm bones, femoral bones and skulls (Dely 1967, 1978), taking into account the fronto-parietale in case of amphibians. The number of vertebrate prey was evaluated based on the highest number of a certain type of body remains. Whenever it was possible, specimens were identified to species level. For determining biomass, weight of the prey species was derived from various literature (Dely 1967, 1978, Topál 1969, Goddard 1984, Ujhelyi 1989, Petrescu 1994, Fattorini et al. 1999, Grzywaczewski et al. 2006, Kitowski \& Pawlega 2010, Romanowski et al. 2013).

\section{Data analysis}

Mean pellet number was determined for each site for each study year. Mean pellet number was also calculated per individuals, taking into account the successfully fledged juveniles and the female adult bird, which predominantly drops the pellets inside the nest box during the breeding season. Distribution of individual number and biomass of vertebrate prey taxa were examined for each site and year.

\section{Results}

The number of collected and dissected owl pellets was 2,094 in 2015 and 2,024 in 2016, respectively (4,118 altogether); these were collected from the same 20 nest-boxes located in the three study sites: 12 in Upper Kiskunság Puszta, 7 in Peszéradacs Meadows, and a single in Upper Kiskunság Lakes. In all of the nest boxes the hatching was successful in both years. Further data on the sampling were summarized in Table 1. The number of owlets that have successfully left their nest boxes was 62 in 2015 (3.1 in average), and 69 in 2016 (3.45 in average); the average number of owl pellets per nest-box was 105 in 2015 and 101 in 2016. Based on these datasets and considering the habits and methods of regurgitation of pellets in adult and pullus individuals during the nesting period (March-September), the average rate of pellet regurgitation was 25.57 pellets/ind. in 2015, and 27.74 pellets/ind. in 2016. 
Table 1. Summary of Little Owl pellet sampling parameters and the total number of pellets per area

1. táblázat A kuvik köpetminták gyűjtésének fontosabb adatai és a teljes köpetszám területegységenként

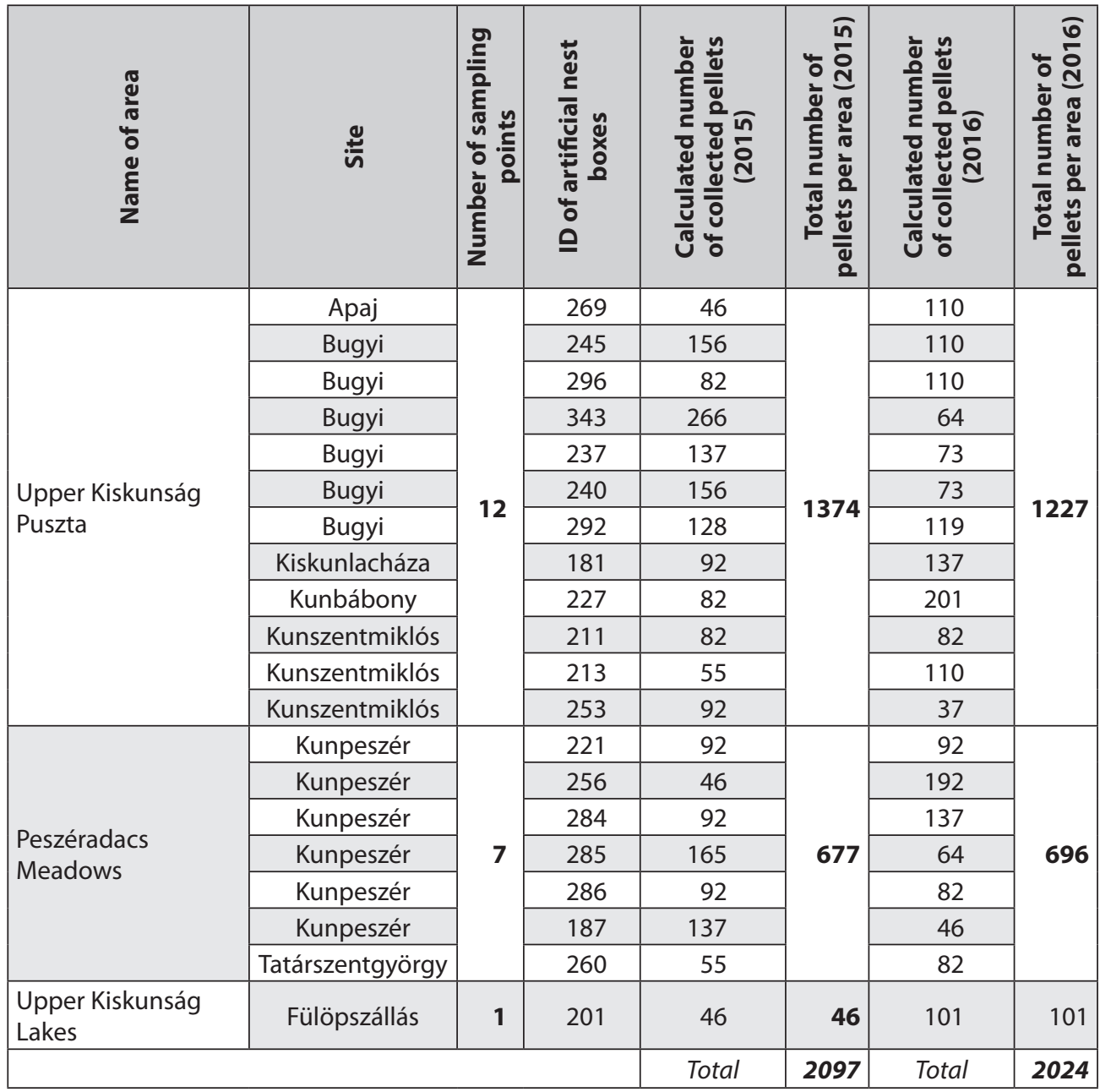

A total of 2,017 vertebrate preys were determined from the 40 samples $(4,118$ owl pellets), (935 from the year 2015 and 1,082 from 2016). The total number of species identified in the samples was 21, including 12 mammalian, 1 amphibian, 4 reptile and 4 bird species. Relative proportion of each prey categories as mammals, amphibians, reptiles and birds is presented in Figure 1.

According to the prey communities, it is clear that in the examined area there is no material difference in the proportions based on the results of the two collection years. Mammals were dominant in the food (average 50.83\%), and the consumption of amphibians was similar (average 48.06\%). According to our data, the consumption of birds and reptiles was not significant, predation of these groups rarely occurred (birds and reptiles totalled $2.22 \%$ ). 


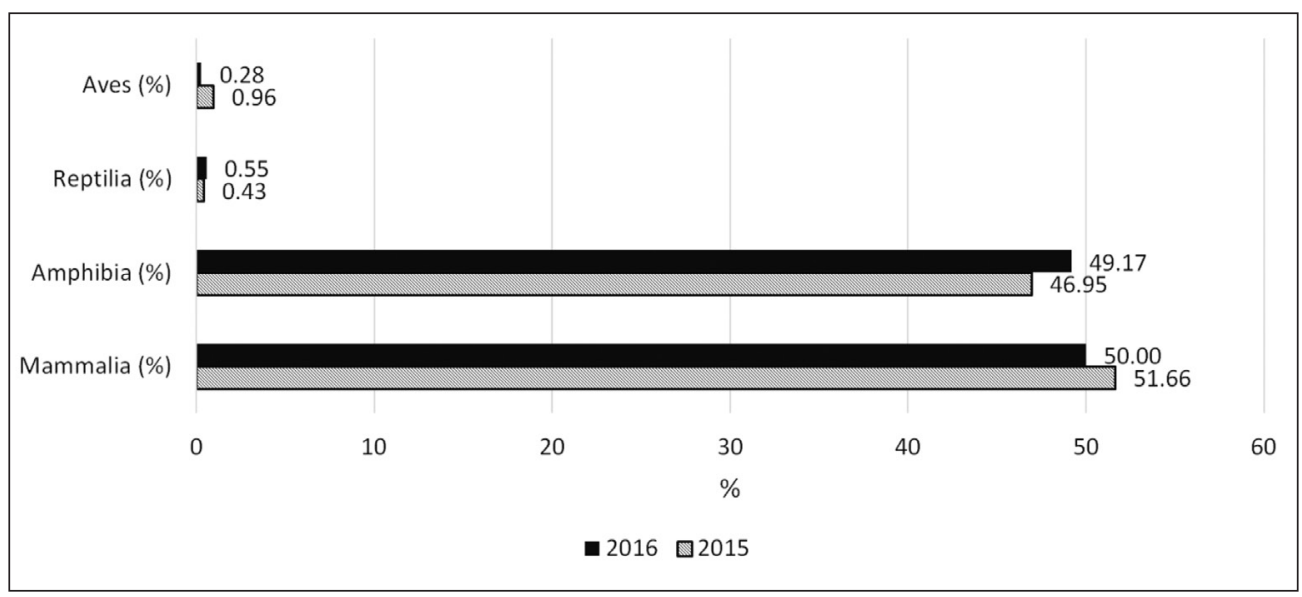

Figure 1. Proportion of vertebrate diet of Little Owls (period March-September in 2015 and 2016; $\mathrm{N}_{2015}=935$ and $\mathrm{N}_{2016}=1018$ prey individuals)

1. ábra A kuvik gerinces zsákmányállatainak összesített megoszlása (2015 és 2016 március-október; 935 és 1018 meghatározott egyed alapján)

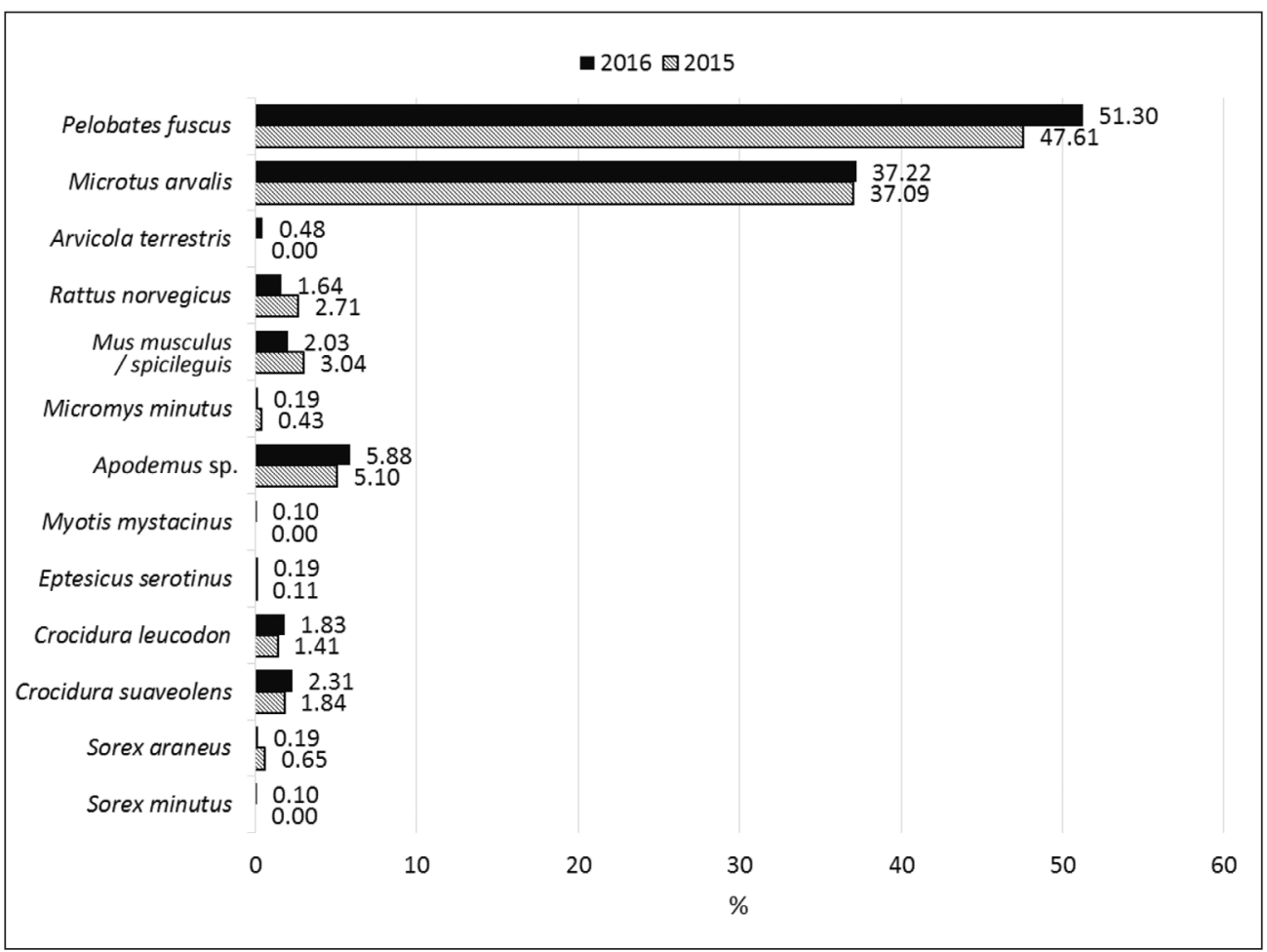

Figure 2. Proportion of mammal and amphibian preys by taxon in 2015 and 2016

2. ábra Emlősök és kétéltűek taxononkénti megoszlása 2015-ben és 2016-ban 
Table 2. Vertebrate food composition of the Little Owl in the study sites; $g$ - grams, $N$ - number of prey, $m$ - pray biomass

2. táblázat A kuvik gerincestáplálék-összetétele a vizsgált élőhelyeken; $g$-gramm, $N$ - zsákmányállatok száma, $m$ - zsákmányállatok biomassza tömege

\begin{tabular}{|c|c|c|c|c|c|c|c|c|c|c|c|c|c|}
\hline \multirow{3}{*}{ Taxa } & \multirow{3}{*}{ 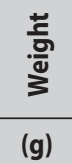 } & \multicolumn{4}{|c|}{ Felső-Kiskunsági Puszta } & \multicolumn{4}{|c|}{ Felsö-Kiskunsági Tavak } & \multicolumn{4}{|c|}{ Peszéradacsi rétek } \\
\hline & & \multicolumn{2}{|c|}{2015} & \multicolumn{2}{|c|}{2016} & \multicolumn{2}{|c|}{2015} & \multicolumn{2}{|c|}{2016} & \multicolumn{2}{|c|}{2015} & \multicolumn{2}{|c|}{2016} \\
\hline & & $\% N$ & $\% \mathrm{~m}$ & $\% N$ & $\% \mathrm{~m}$ & $\% N$ & $\% \mathrm{~m}$ & $\% N$ & $\% \mathrm{~m}$ & $\% N$ & $\% \mathrm{~m}$ & $\% N$ & $\% \mathrm{~m}$ \\
\hline Class AMPHIBIA & & 51.16 & 31.96 & 46.26 & 35.85 & 0.00 & 0.00 & 56.82 & 46.62 & 41.46 & 21.30 & 54.41 & 27.05 \\
\hline Pelobates fuscus & 20.0 & 51.16 & 31.96 & 46.26 & 35.85 & & & 56.82 & 46.62 & 41.46 & 21.30 & 54.41 & 27.05 \\
\hline REPTILIA & & 0.33 & 1.88 & 0.85 & 0.57 & 0.00 & 0.00 & 0.00 & 0.00 & 0.63 & 0.63 & 0.00 & 0.00 \\
\hline Podarcis taurica & 18.5 & & & 0.71 & 0.51 & & & & & & & & \\
\hline Lacerta agilis & 12.5 & 0.17 & 0.06 & 0.14 & 0.07 & & & & & 0.32 & 0.10 & & \\
\hline $\begin{array}{l}\text { Coronella } \\
\text { austriaca }\end{array}$ & 65.0 & & & & & & & & & 0.32 & 0.53 & & \\
\hline Emys orbicularis & 350.0 & 0.17 & 1.82 & & & & & & & & & & \\
\hline Class AVES & & 1.16 & 1.73 & 0.14 & 0.13 & 0.00 & 0.00 & 0.00 & 0.00 & 0.63 & 0.81 & 0.61 & 0.80 \\
\hline Motacilla flava & 18.0 & 0.17 & 0.09 & & & & & & & 0.32 & 0.15 & & \\
\hline Motacilla alba & 23.0 & 0.33 & 0.24 & & & & & & & & & & \\
\hline Passer montanus & 24.0 & 0.17 & 0.12 & 0.14 & 0.13 & & & & & & & 0.30 & 0.18 \\
\hline Sturnus vulgaris & 82.0 & 0.50 & 1.28 & & & & & & & 0.32 & 0.67 & 0.30 & 0.62 \\
\hline \begin{tabular}{|l} 
Class \\
MAMMALIA
\end{tabular} & & 47.34 & $\mid 64.43$ & 52.61 & 63.39 & 100.0 & 100.0 & 43.18 & 53.38 & 56.96 & 77.21 & 44.98 & 72.14 \\
\hline Sorex minutus & 5.0 & & & 0.14 & 0.03 & & & & & & & & \\
\hline Sorex araneus & 10.0 & 0.50 & 0.16 & & & & & & & 0.95 & 0.24 & 0.30 & 0.08 \\
\hline $\begin{array}{l}\text { Crocidura } \\
\text { suaveolens }\end{array}$ & 5.0 & 1.50 & 0.23 & 2.82 & 0.55 & 11.76 & 2.04 & & & 1.90 & 0.24 & 1.22 & 0.15 \\
\hline \begin{tabular}{|l|} 
Crocidura \\
leucodon
\end{tabular} & 10.5 & 1.00 & 0.33 & 1.27 & 0.52 & & & 2.27 & 0.98 & 2.22 & 0.60 & 2.74 & 0.71 \\
\hline Apodemus sp. & 25.0 & 4.32 & 3.37 & 5.36 & 5.19 & & & 4.55 & 4.66 & 6.65 & 4.27 & 6.38 & 3.97 \\
\hline $\begin{array}{l}\text { Micromys } \\
\text { minutus }\end{array}$ & 5.0 & 0.50 & 0.08 & 0.28 & 0.05 & & & & & & & & \\
\hline $\begin{array}{l}\text { Mus musculus et } \\
\text { spicilegus }\end{array}$ & 21.0 & 1.66 & 1.09 & 2.40 & 1.95 & & & & & 5.70 & 3.07 & 1.22 & 0.63 \\
\hline Rattus norvegicus & 375.0 & 1.99 & 23.35 & 0.28 & 4.10 & & & & & 4.11 & 39.64 & 4.56 & 42.51 \\
\hline Arvicola terrestris & 125.0 & & & 0.42 & 2.05 & & & & & & & 0.61 & 1.89 \\
\hline Microtus arvalis & 32.0 & 35.71 & 35.69 & 39.35 & 48.79 & 88.24 & 97.96 & 36.36 & 47.74 & 35.44 & 29.14 & 27.66 & 22.01 \\
\hline \begin{tabular}{|l} 
Eptesicus \\
serotinus
\end{tabular} & 26.0 & 0.17 & 0.13 & 0.14 & 0.14 & & & & & & & 0.30 & 0.20 \\
\hline \begin{tabular}{|l} 
Myotis \\
mystacinus
\end{tabular} & 5.0 & & & 0.14 & 0.03 & & & & & & & & \\
\hline \multicolumn{2}{|c|}{ Species richness } & \multicolumn{2}{|c|}{16} & \multicolumn{2}{|c|}{15} & \multicolumn{2}{|r|}{2} & \multicolumn{2}{|r|}{4} & \multicolumn{2}{|c|}{12} & \multicolumn{2}{|c|}{12} \\
\hline \multicolumn{2}{|c|}{$\begin{array}{r}\text { Cumulative species } \\
\text { richness }\end{array}$} & \multicolumn{4}{|c|}{20} & & \multicolumn{4}{|c|}{15} \\
\hline
\end{tabular}


Based on the results of Figure 1, only the mammals and amphibians, by taxonomic distribution, are evaluated as percentages (Figure 2).

Dominance of the Common Spadefoot (Pelobates fuscus) was the highest among the prey items; its relative proportion was similar in both years (47.61 and 51.3\%), and it was followed by the Common Vole (Microtus arvalis) by approx. 37\% proportion. The next items were far behind of these two species, and they did not reach even 6\%. Field mice (Apodemus sp.) reached 5.1 and $5.88 \%$, while the occurrence of other items was insignificant (see Table 2). By the number of species identified in a given site, the most species (20 vertebrate species) were found in the Upper Kiskunság Puszta. In all three sites and in both study years, except for Upper Kiskunság Lakes in 2015, mammals and amphibians were present in roughly the same number. Amphibians were represented by a single species, the Common Spadefoot in remarkably high proportions. Based on the identified prey items, mammals were dominated in almost all of the years and sites. Their proportion was the lowest in Peréradacs Meadows in 2016 (44.98\%), and it was exceeded even by the Common Spadefoot (54.41\%). Predation on Common Vole was detected in all three areas in 27.66 and 88.24\%; the Common Spadefoot was absent only in the samples of the Upper Kiskunság Lakes collected in 2015. However, its proportion was the highest in all of the years if we analysed the dataset by species and not by higher taxonomical units, except at the Upper Kiskunság Lakes in 2015. The second most common mammal prey was the Field Mice (Apodemus sp.) by $4.32-665 \%$, while the proportion of the House Mouse/Mound-building Mouse (Mus musculus, M. spicilegus) was lower $(1.2-5.7 \%)$, and they were completely missing from the samples of Upper Kiskunság Lakes. Brown Rat (Rattus norvegicus) was also found in quite high numbers in the samples of the Peszéradacs Meadows in 2016 (4.56\%). Besides the rodent species, several shrew species (Soricomorpha) were also identified such as the Lesser White-toothed Shrew (Crocidura suaveolens), the Bicolored Shrew (C. leucodon), the Eurasian Pygmy Shrew (Sorex minutus) and the Common Shrew (S. araneus). Bats were represented by 3 individuals of the Serotine Bat (Eptesicus serotinus) and a single specimen of the Whiskered Bat (Myotis mystacinus) (Table 2). Proportion of the birds was generally low and varied depending on the specificity of the territory. Their proportion exceeded $1 \%(1.16 \%)$ only in a single case, in the Upper Kiskunság Puszta area in 2015. Their highest proportion was recorded in the samples of the Upper Kiskunság Puszta, while they were completely missing from the samples of Upper Kiskunság Lakes.

Regarding birds, the Starling (Sturnus vulgaris) proved to be the most commonly predated species, but other species closely related to farmland habitats; White Wagtail (Motacilla alba), Western Yellow Wagtail (Motacilla flava), Eurasian Tree Sparrow (Passer montanus) were also hunted by the owls. Though predation on reptiles was insignificant (a total of $1.81 \%$ in this study), emergence of the Smooth Snake (Coronella austriaca) among prey items was remarkable. Besides this, reptiles were represented by few individuals of the Sand Lizard (Lacerta agilis) and the Balkan Wall Lizard (Podarcis taurica), and a juvenile European Pond Turtle (Emys orbicularis), which was found in a nest box located close to a fishpond.

The high proportion of the two dominant species (Common Spadefoot and Common Vole) was also clearly reflected in the biomass amounts. The rate by weight of Common Vole in all 
sites and years, except for the 2016 collections of Peszéradacs Meadows, slightly exceeded the weight ratio of the Common Spadefoot. Although the majority of species were dominated by the Common Spadefoot, predominance of the Common Vole was dominant in the weight and nutritional aspects of the breeding season (March-September). Furthermore, the total biomass of amphibians, reptiles and birds did not approach mammalian in neither of the cases. Based on these results, generally it can be stated that at the level of animal communities, the surveyed Little Owl population primarily preferred mammals and secondly amphibians in their diet.

\section{Discussion}

The Little Owl is basically a generalist predator, its hunting behaviour is adapted to the availability of potential prey species (Cramp 1985, Schönn et al. 1991, Laiu \& Murariu 1997, Van Nieuwenhuyse et al. 2008, Śálek et al. 2010). As it was already previously known, it hunts for a wide variety of prey due to its large distribution area and various hunting techniques (Mikkola 1983, Cramp 1985, Angelici et al. 1997, Van Nieuwenhuyse et al. 2008). This is well reflected in the prey composition of Little Owls of different geographical regions (Shehab et al. 2004, Charter et al. 2006, Kayahan \& Tabur 2016), and in different habitats within the same geographical region (Van Nieuwenhuyse et al. 2008, Apolloni et al. 2018). The role of small mammals in the Southern European region is generally less important; however, vertebrates can be dominant in some Mediterranean regions (Goutner \& Alivizatos 2003); in Central Europe the proportion of small mammals is usually high (Zerunian et al. 1982, Mánez 1983, Schönn et al. 1991, Ille 1992, Genot \& Van Nieuwenhuyse 2002, Gorzel \& Grzywaczewski 2003, Tomé et al. 2008, and the present study).

Within vertebrates, the proportion of mammals $(43.18-100 \%)$ was less than it was reported by previous Hungarian (Greschik 1911, 1924, Schmidt 1967, Marián \& Schmidt 1968, Lanszki 2006) and Central European studies (Romanowski 1988, Ille 1992, Génot \& Bersuder 1995, Laiu \& Murariu 2000, Schmid 2003, Georgiev 2005, Grzywaczewski et al. 2006, Romanowski \& Zmihorski 2006, Kitowski \& Pawlega 2010, Romanowski et al. 2013 ) due to the predominance of amphibians. Contrary to other Hungarian studies (Greschik 1911, 1924, Marián \& Schmidt 1968, Molnár 1984, Andrési \& Sódor 1986, Endes 1990, Kovács \& Cserkész 2005, Lanszki 2006), amphibians gave the most to the prey of Little Owls in this study.

The Common Spadefoot was the most frequent prey, which was followed by the Common Vole, a common species of grasslands and agricultural fields. Since only very few records exist on higher rates of amphibians in owl pellets (Uttendörfer 1939, Festetics 1955), the observed high proportion of the Common Spadefoot in the Little Owl pellets merits a special mention. Although, some authors emphasized the importance of seasonal availability of frog species (Mikkola 1983), none of the Hungarian and Central European studies have found so far such a high proportion of amphibians (including the Common Spadefoot); generally, the proportion of amphibians remains under $5 \%$.

The Common Spadefoot was totally missing from the samples of Upper Kiskunság Lakes in 2015; this was when the owls switched their prey preference and started to hunt for 
Common Voles, which consisted $88.24 \%$ of their prey items. However, in 2016 the results were already similar to the other sites with a proportion of $56.82 \%$ the Common Spadefoot. This could be explained by the dry weather of February-April 2015 when the water-covered areas were reduced, and the salt lakes on the periphery area dried out. These effects could have had a significant impact on the abundance of the Common Spadefoot. Although the Little Owl is considered to be a generalist raptor, it seems by the large number of frogs in its diet, that it is apt to hunt opportunistically if the prey is abundant enough and easy to catch. For an owl it is easy to hunt for frogs at sunset, especially if they are concentrated in a relatively small area (Nyström et al. 2002). The weight of the Common Spadefoot is similar to that of the Common Vole (Dely 1967) and compared to other prey species, it can be hunted with a lower energy investment.

Remnants of Mus species, often representing a significant source of food (Chenchouni 2014), were found in all of the sampling sites, where livestock farms located within the territory of the owl. However, unlike in other studies carried out in Hungary (e.g. Marián \& Schmidt 1968), the number of mice was low, despite the numerous buildings and objects present within most of the territories. Similar to other studies, larger body sized species (e.g. European Pond Turtle, Smooth Snake, Brown Rat, bats) appeared rarely (Schmidt 1998, Van Nieuwenhuyse et al. 2008, Kayahan \& Tabur 2016); however, in the Middle East region several bat species were consumed in large numbers (Shehab et al. 2004).

Reptilians play an important role in the food composition of the Little Owl, especially in the Mediterranean region (Mastrorilli et al. 2001, Arcidiacono et al. 2007). However, in Central Europe, reptiles are less preferred, which is also reflected in our results. According to our analyses, reptiles were marginal and the fishes were completely absent from the diet; although, some authors noted regular presence of these items in Little Owl pellets (Mikkola 1983, Angelici et al. 1997, Schmidt 1998). In general, birds do not play a key role in the diet of the Little Owl (Laursen 1981, Cramp 1985, Lanszki 2006, Romanowski et al. 2013). Similar to other Central European studies (Simeonov 1983), the importance of passerines were small because for the Little Owl, these small birds are difficult to hunt. Among bird species, the Starling proved to be the most commonly caught prey, but bird species like the White Wagtail (Motacilla alba), the Western Yellow Wagtail (M. flava) and the Eurasian Tree Sparrow (Passer montanus), closely related to other farmland habitats, were also preyed by Little Owls. These songbirds are definitely connected also to grassland habitats (Marián \& Schmidt 1968, Grzywaczewski et al. 2006, Shao \& Liu 2008, Kitowski \& Pawlega 2010, Pocora et al. 2012). The lack of birds in the owl pellets collected in the Upper Kiskunság Lakes can be explained by the habitat characteristics, being a large open area, free from any trees and bushes.

Previous studies on demographic and dispersion subjects in the research area found that the Little Owl population of the Upper Kiskunság was strongly delimited by the availability of nesting sites, which was also supported by the fact that in 2016: $34.2 \%$ of the artificial nest boxes were occupied by Little Owls (Hámori et al. 2017b). Thus, successful occupation of the nest boxes for breeding purposes contributes significantly to the increasing number of breeding pairs in the study area. Moreover, this also demonstrates that besides the successful conservation of the species (Leigh 2001, Gottschalk et al. 2011) the nest box provides novel 
opportunities for feeding ecological studies. The new owl pellet collecting method (samples derived from artificial nesting boxes) used also in this study might have also contributed to the differences compared to previous observations made by earlier feeding biological studies of the Central European region. These types of collections are important because they contain pellets of both the parents and owlets, produced during the periods of pairing, egg laying and incubation up until the fledging of owlets and the beginning of dispersal. Another great advantage of these materials is that we could determine not only the material usually present in the owl pellets but also the lacerated but not ingested remains of prey items (e.g. Common Spadefoot, Passeridae). In the area of the Upper Kiskunság Puszta we could record the almost entire spectrum (20 vertebrate species). In the Peszéradacs Meadows 15, while in the Upper Kiskunság Lakes only 5 species were identified, which can be explained by the lower available sample sizes. The high diversity of the Upper Kiskunság Puszta is mainly due to the mosaic habitat structure, the dense network of livestock farms and the high proportion of grasslands managed by traditional extensive methods. Here, half of the nest boxes $(\mathrm{N}=6)$ were located in Juhászföld and Ürböpuszta belonging to the outer region of Bugyi city, which had high breeding outputs compared to other nets boxes between 2012 and 2016 with 4.63 successfully fledged owlets per nest box (Hámori 2017a). This also demonstrates that the area provides excellent habitat conditions for the Little Owls.

Based on these results, it can be stated that regarding hunting strategy and prey preference the Little Owls are able to adapt easily to characteristics of their habitat and prey resource. The 21 vertebrate prey species identified represent a relatively broad range of available prey source and provide important information not only for feeding biology, but also for the conservation of the Little Owl. In the future, we need to encourage further feeding biology analyses in other lowland regions of Hungary by collecting owl pellets from the operating nest box network. In addition, similarly to recent Western European studies (e.g. Alivizatos et al. 2006, Lanszki 2006, Romanowski et al. 2013), seasonal analyses are also needed, not only for vertebrate prey species, but also for predated arthropods, earthworms, potentially consumed plant substances and their derivatives.

\section{Acknowledgements}

We are deeply indebted the members of the Hungarian Little Owl Protecting Public Benefit Association for their help in the field work. We would like to thank Dalma Bátkay for language editing of our manuscript. Anonymous reviewers provided helpful comments that improved the manuscript. This article was made in frame of the „EFOP-3.6.1-16-2016-00018Improving the role of research+development+innovation in the higher education through institutional developments assisting intelligent specialization in Sopron and Szombathely". 


\section{References}

Alivizatos, H., Goutner, V. \& Zogaris, S. 2005. Contribution to the study of the diet of four owl species (Aves, Strigiformes) from mainland and inland areas of Greece. - Belgian Journal of Zoology 135: 109-118.

Alivizatos, H., Goutner, V., Athanasiadis, A. \& Poirazidis, K. 2006. Comparative temporal prey use by Barn Owl (Tyto alba) and Little Owl (Athene noctua) in the Evros Delta, northeastern Greece. - Journal of Biological Research 6: 177-186.

Andrési, P. \& Sódor, M. 1986. Adatok fészkelő bagolyfajaink táplálkozásökológiájához [Foraging ecology of some owl species]. - A Magyar Madártani Egyesület II. Tudományos Ülése, Szeged, pp. 293-300. (in Hungarian)

Angelici, F. M., Latella, L., Luiselli, L. \& Riga, F. 1997. The summer diet of the Little Owl (Athene noctua) on the Island of Astipalaia (Dodecanese, Greece). - Journal of Raptor Research 3: 280-282.

Apolloni, N., Grüebler, M. U., Arlettaz, R., Gottschalk, T. K. \& Naef-Daenzer, B. 2018. Habitat selection and range use of little owls in relation to habitat patterns at three spatial scales. - Animal Conservation 21(1): 6575. DOI: $10.1111 /$ acv.12361

Arcidiacono, G., Donati, C. \& Mastrorilli, M. 2007. Dieta della Civetta Athene noctua in habitat naturali e antropizzati: una revisione bibliografica [Diet of the Little Owl Athene noctua in rural and urban areas: a bibliographical review]. - Studi Trentini di Scienze Naturali, Acta Biologica 83: 243-247. (in Italian)

Báldi, A. \& Batáry, P. 2011. The past and future of farmland birds in Hungary. - Bird Study 58(3): 365-377. DOI: 10.1080/00063657.2011.588685

BirdLife International 2016. Athene noctua. - The IUCN Red List of Threatened Species 2016: e. T22689328A86869477. DOI: 10.2305/IUCN.UK.2016-3.RTS.T22689328A86869477.en

Bozó, L. \& Csathó, A. I. 2017. The status and population changes of the Little Owl (Athene noctua) in the south of Békés County (Hungary). - Ornis Hungarica 25(2): 23-33. DOI: 10.1515/orhu-2017-0013

Brown, R., Ferguson, J., Lawrence, M. \& Lees, D. 1988. Federn, Spuren und Zeichen der Vögel Europas [Pens, traces and signs of European birds]. - Aula-Verlag, Wiesbaden (in German)

Charter, M., Leshem, Y., Izhaki, I., Guershon, M. \& Kiat, Y. 2006. The diet of the Little Owl, Athene noctua, in Israel. - Zoology in the Middle East 39(1): 31-40. DOI: 10.1080/09397140.2006.10638180

Chenchouni, H. 2014. Diet of the Little Owl (Athene noctua) during the pre-reproductive period in a semi-arid Mediterranean region. - Zoology and Ecology 24(4): 314-323. DOI: 10.1080/21658005.2014.965919

Cramp, S. (ed.) 1985. Handbook of the Birds of Europe, the Middle East and North Africa. The Birds of the Western Palearctic, Vol. 4. - Oxford University Press, Oxford, pp. 514-525.

Debrot, S., Fivaz, G., Mermod, C. \& Weber, J. M. 1982. Atlas des poils des mammifères d'Europe [Europe's hairs atlas of mammals]. - Institut de Zoologie, Neuchatel (in French)

Dely, O. Gy. 1967. Kétéltüek - Amphibia. - Magyarország Állatvilága (Fauna Hungariae) 20(3): 1-80. (in Hungarian)

Dely, O. Gy. 1978. Hüllők - Reptilia. - Magyarország Állatvilága (Fauna Hungariae) 20(4): 1-128. (in Hungarian)

Diesener, G. \& Reicholf, J. 1997. Amphibians and Reptilians. - Warsaw, Swiat Ksiazki, Poland

Endes, M. 1990. Kuvik (Athene noctua) ürgefogyasztása [Little Owl (Athene noctua) feeding on Ground Squirrel]. - Calandrella 4(1): 85. (in Hungarian)

Fattorini, S., Manganaro, A., Piattella, E. \& Salvati, L. 1999. Role of the beetles in Raptor diets from a Mediterranean urban area. - Fragmenta Entomologica 31: 57-69.

Festetics, A. 1955. Megfigyelések a gyöngybagoly és kuvik életéröl [Observations on the life of Barn Owl and Little Owl]. - Aquila 59-62: 401-403.

Génot, J-C. 1994. Breeding biology of the Little Owl Athene noctua in France. - In: Meyburg, B-U. \& Chancellor, R. D. (eds.) Raptor Conservation. - WWGBP/The Pica Press, Berlin, pp. 511-520.

Génot, J-C. \& Bersuder, D. 1995. Le régime alimentaire de la Chouette chevêche Athene noctua Alsace-Lorraine [The diet of the Little Owl Athene noctua in Alsace-Lorraine]. - Ciconia 19: 35-51. (in French)

Génot, J-C. \& Van Nieuwenhuyse, D. 2002. Little Owl Athene noctua. - Birds of Western Palearctic Update 4: 35-63.

Georgiev, D. G. 2005. Food niche of Athene noctua (Scopoli, 1769) and Tyto alba (Scopoli, 1769) (Aves, Strigiformes) co-existing in one region of the Upper Tracian Valley (South Bulgaria). - Animalia 41: 115-122.

Glutz Von Blotzheim, U. \& Bauer, K. 1980. Handbuch der Vögel Mitteleuropas, Band 9. [Handbook of the birds of Central Europe, Vol. 9.]. - Aula-Verlag, Wiesbaden (in German) 
Goddard, P. 1984. Morphology, growth, food habits and population characteristics of the Smooth Snake Coronella austriaca in southern Britain. - Journal of Zoology 204: 241-257.

Gorman, G. 1995. The status of owls (Strigiformes) in Hungary. - Buteo 7: 95-108.

Gorzel, M. \& Grzywaczewski, G. 2003. Feed of Little Owl (Athene noctua Scop. 1769) in agricultural landscape of the Lublin area. - Acta Agrophysica 1(3): 433-440.

Gottschalk, T. K., Ekschmitt, K. \& Wolters, V. 2011. Efficient placement of nest boxes for the Little Owl (Athene noctua). - Journal of Raptor Research 45(1): 1-14. DOI: 10.3356/JRR-09-11.1

Goutner, V. \& Alivizatos, H. 2003. Diet of the Barn Owl Tyto alba and Little Owl Athene noctua in wetlands of northeastern Greece. - Belgian Journal of Zoology 133: 15-22.

Greschik, J. 1911. Hazai ragadozó madarak gyomor- és köpettartalom vizsgálatai II. Baglyok [Stomach and pellet analyses of our native birds of prey II. Owls]. - Aquila 18: 156-158. (in Hungarian)

Greschik, J. 1924. Gyomor- és köpettartalom vizsgálatok. Adatok hazánk apró emlőseinek faunájához [Stomach and pellet analyses. Data on the native small mammal fauna]. - Aquila 30-31: 243-263. (in Hungarian)

Grzywaczewski, G., Kitowski, I. \& Scibior, L. 2006. Diet of Little Owl Athene noctua during breeding in the central part of Lublin region. - Acta Zoologica Sinica 52(6): 1155-1161.

Hadarics, T. \& Zalai, T. 2008. Magyarország madarainak névjegyzéke - Nomenclator Avium Hungariae - An annotated list of the birds of Hungary. - MME, Budapest, p. 148. (in Hungarian)

Hámori, D. 2012. Kuvikodú-telepítés szempontjai alföldi területeken [Criteria for installing nest boxes for Little Owl (Athene noctua) in the lowland areas]. - Heliaca 10: 61-63. (in Hungarian)

Hámori, D. 2017a Kuvikvédelem egy közép-magyarországi mezőgazdasági területen: költési adatok és a mesterséges fészekodvak paramétereinek összefüggései [Little Owl conservation in farmland areas of Central Hungary: relationships between the nesting data and nestbox parameters]. - Magyar Apróvad Közlemények 13: 187-199. DOI: 10.17243/mavk.2017.187 (in Hungarian)

Hámori, D. 2017b Kuvik [Little Owl]. - In: Hámori, D. \& Csörgő, T. (eds.) 2017. Magyarországon előforduló bagolyfajok határozása és gyakorlati természetvédelme [Determination and conservation of owls occurring in Hungary]. - Herman Ottó Intézet, Budapest, pp. 62-69. (in Hungarian)

Hámori, D., Szél, Gy. \& Winkler, D. 2017a Food composition of the Little Owl (Athene noctua) in a farmland area of Central Hungary, with particular attention to arthropod diversity. - Ornis Hungarica 25(2): 34-50. DOI: 10.1515/orhu-2017-0014

Hámori, D., Winkler, D. \& Vadász, Cs. 2017b Demographic data on the Little Owl (Athene noctua) in Upper-Kiskunság (Hungary). - Ornis Hungarica 25(2): 11-22. DOI: 10.1515/ orhu-2017-0012

Haraszthy, L. 1982. Kuvik-odú készítése [Making of nest boxes for Little Owl]. - Madártani Tájékoztató, oktdec.: 259-262. (in Hungarian)

Heath, M., Borggreve, C., Peet, N. \& Hagemeijer, W. 2000. European bird populations: estimates and trends. Cambridge: Bird Life International, Bird Life Series 10: 1-160.

Herrera, C. M. \& Hiraldo, F. 1976. Food-niche and trophic relationships among European owls. - Ornis Scandinavica 7: 29-41. DOI: 10.2307/3676172

Ille, R. 1992. Zur Biologie und Ökologie des Steinkauzes (Athene noctua) im Marchfeld: Aktuelle Situation und mögliche Schutzmanahmen [Contributions to the biology and ecology of Little Owl (Athene noctua) in Marchfeld: actual situation and possible preservation]. - Egretta 35: 49-57. (in German)

Kayahan, A. \& Tabur, M. A. 2016. Diet composition of Little Owl (Athene noctua Scopoli, 1769) in Turkey. - Pakistan Journal of Zoology 48(4): 943-948.

Kessler, J. 2015. Osteological guide of songbirds from Central Europe. - Ornis Hungarica 23(2): 62-155. DOI: 10.1515/orhu-2015-0016

Kitowski, I. \& Pawlega, K. 2010. Food composition of the Little Owl Athene noctua in farmland areas of South East Poland. - Belgian Journal of Zoology 140(2): 203-211.

Kollárik, A. 1999. Magyarország nemzeti parkjai és a nemzeti parkok igazgatóságainak müködési területe [National parks of Hungary and operation's areas of national parks]. - Tapolca, p. 23. (in Hungarian)

Kovács, E. Zs. \& Cserkész, T. 2005. A Hevesi-sík kisemlős faunája bagolyköpetek vizsgálata alapján [Small mammal fauna of the Hevesi plain region based on owl pellet analysis]. - Folia Historico Naturalia Musei Matraensis 29: 195-202. (in Hungarian)

Laiu, L. \& Murariu, D. 1997. Diet of the Little Owl (Athene noctua) during summer in a sub-Carpathian depression of Moldovia - Romania. - Travaux du Muséum National d'Histoire Naturelle "Grigore Antipa" 37: $319-326$. 
Laiu, L. \& Murariu, D. 2000. Food of the Little Owl (Athene noctua Scop., 1769) (Aves: Strigiformes) in the surroundings of Bucharest (Romania). - Travaux du Muséum National d'Histoire Naturelle "Grigore Antipa" 42: 185-193.

Lanszki, J. 2006. A kuvik (Athene noctua) táplálék-összetétele egy Somogy megyei külvárosi élőhelyen [Seasonal diet composition of Little Owl (Athene noctua) in a suburban habitat, Somogy County]. - Natura Somogyiensis 9: 315-324. (in Hungarian)

Laursen, J. T. 1981. Kirkeuglens Athene noctua fødevalg i Østjylland [Prey of the Little Owl Athene noctua in East Jutland]. - Dansk Ornitologisk Forenings Tidsskrift 75: 105-110. (in Danish)

Le Gouar, P. J., Schekkerman, H., Van der Jeugd, H. P., Boele, A., Van Harxen, R., Fuchs, P., Stroeken, P. \& Van Noordwijk, A. J. 2011. Long-term trends in survival of a declining population: the case of the Little Owl (Athene noctua) in the Netherlands. - Oecologia 166: 369-379. DOI: 10.1007/s00442-010-1868-x

Leigh, R. 2001. The breeding dynamics of Little Owls (Athene noctua) in North West England. - In: Génot, J. C., Lapios, J. M., Lecomte, P. \& Leigh, R. S. (eds.) Chouette chevêche et territoires. Actes du Colloque International de Champ-sur-Marne, November 25-26, 2000. ILOWG. - Ciconia 25: 67-76.

Mánez, M. 1983. Espectro alimentacio del Mochuelo común (Athene noctua) en Espána [The diet spectrum of Little Owl (Athene noctua) in Spain]. - Alytes 1: 275-290. (in Spanish)

Mánez, M. 1994. Little Owl Athene noctua. - In: Tucker, G. M., Heath, M. F., Tomialojc, L. \& Grimmett, R. F. A. (eds.) Birds in Europe: their conservation status. - Bird Life Conservation Series 3: 322-323.

Marián, M. \& Schmidt, E. 1968. Adatok a kuvik (Athene noctua (Scop.)) gerinces táplálékának ismeretéhez Magyarországon [Contribution to the knowledge on the vertebrate diet of Little Owl]. - Móra Ferenc Múzeum Évkönyve 1966-67, Szeged, pp. 271-275. (in Hungarian)

März, R. 1987. Gewöll- und Rupfungskunde [Handbook of bird pellets and droppings]. - Akademie Verlag, Berlin (in German)

Mastrorilli, M., Sacchi, R. \& Gentilli, A. 2001. Importanza dell'erpetofauna nella dieta degli Strigiformi italiani [Importance of the herpetofauna in the diet of Strigiformes in Italy]. - Pianura 13: 339-342. (in Italian)

Mikkola, H. 1983. Owls of Europe. - T \& AD Poyser, Calton

Milchev, B. \& Spassov, N. 2017. First evidence for carrion-feeding of Eurasian Eagle-owl (Bubo bubo) in Bulgaria. - Ornis Hungarica 25(1): 58-69. DOI: 10.1515/orhu-2017-0005

Móczár, L. (ed.) 1984. Állathatározó I-II. 3. átdolgozott kiadás [Animal identification I-II.]. - Tankönyvkiadó, Budapest (in Hungarian)

Molnár, I. 1984. Bagolytáplálkozási adatok a Dunántúlról [Data on the diet of owls from the Transdanubia]. Madártani Tájékoztató júl-dec.: 106-110. (in Hungarian)

Morris, A. J., Wilson, J. D., Whittingham, M. J. \& Bradbury, R. B. 2005. Indirect effects of pesticides on breeding Yellowhammer (Emberiza citrinella). - Agriculture, Ecosystems and Environment 106: 1-16. DOI: 10.1016/j.agee.2004.07.016

Morris, M. G. 2000. The effects of structure and its dynamics on the ecology and conservation of arthropods in British grasslands. - Biological Conservation 95: 129-142. DOI: 10.1016/S0006-3207(00)00028-8

Newton, I. 2004. The recent declines of farmland bird populations in Britain: an appraisal of causal factors and conservation actions. - Ibis 146: 579-600. DOI: 10.1111/j.1474-919X.2004.00375.x

Nyström, P., Birkedal, L., Dahlberg, C. \& Brönmark, C. 2002. The declining Spadefoot Toad Pelobates fuscus: calling site choice and conservation. - Ecography 25(4): 488-498. DOI: 10.1034/j.1600-0587.2002.250411.x

Obuch, J. \& Krištin, A. 2004. Prey composition of the Little Owl Athene noctua in an arid zone (Egypt, Syria, Iran). - Folia Zoologica 53: 65-79.

Petrescu, A. 1994. Contributions à la connaissance de la nourriture de la Chouette Athene noctua (Aves, Strigiformes) [Contribution to the knowledge on the diet of Little Owl Athene noctua (Aves, Strigiformes)]. Travaux du Muséum National d'Histoire Naturelle "Grigore Antipa" 34: 391-400. (in French)

Pocora, V., Popovici, M., Manci, C. O. \& Iorgu, I. St. 2012. Feeding of the Little Owl during nesting season in the Danube Delta (Romania). - Analele Științifice ale Universității „Alexandru Ioan Cuza” din Iași, s. Biologie animală Tom 58: 107-114.

Rakonczay, Z. (ed.) 2001. A Kiskunságtól Bácsalmásig (A Kiskunság természeti értékei) [From Kiskunság to Bácsalmás (Natural values of Kiskunság)]. - Mezőgazda Kiadó, Budapest (in Hungarian)

Romanowski, J. 1988. Trophic ecology of Asio otus (L.) and Athene noctua (Scop.) in the suburbs of Warsaw. Polish Ecological Studies 14: 223-234.

Romanowski, J. \& Zmihorski, M. 2006. The Little Owl Athene noctua diet in Central Poland. - Notatki Ornitologiczne 47: 203-206. 
Romanowski, J., Altenburg, D. \& Zmihorski, M. 2013. Seasonal variation in the diet of Little Owl, Athene noctua in agricultural landscape of Central Poland. - North-Western Journal of Zoology 9(2): 310-318.

Sageder, G. 1990. Nahrungsspektrum und Mechanismen der Entstehung der Beutewahl beim Steinkauz: Eine vergleichende Freiland- und Laboruntersuchung [Nutrition spectrum and prey boosting mechanisms in Little Owl: comparative field and laboratory test]. - Diss. Univ. Wien, pp. 1-72. (in German)

Šálek, M. \& Schröpfer, L. 2008. Population decline of the Little Owl (Athene noctua Scop.) in the Czech Republic. - Polish Journal of Ecology 56: 527-534.

Šálek, M., Chrenkova, M. \& Kipson, M. 2013. High population density of Little Owl (Athene noctua) in Hortobágy National Park, Hungary, Central Europe. - Polish Journal of Ecology 61(1): 165-169.

Šálek, M., Riegert, J. \& Křivan, V. 2010. The impact of vegetation characteristics and prey availability on breeding habitat use and diet of Little Owls Athene noctua in Central European farmland. - Bird Study 57(4): 495503. DOI: $10.1080 / 00063657.2010 .494717$

Schaub, M., Ullrich, B., Knotzsch, G., Albrecht, P. \& Meisser, C. 2006. Local population dynamics and the impact of scale and isolation: a study on different Little Owl populations. - Oikos 115: 389-400. DOI: 10.1111/j.2006.0030-1299.15374.x

Schmid, P. 2003. Gewöllanalyse bei einer Population des Steinkauzes Athene noctua im Grossen Moos, einer intensiv genutzten Agrarlandschaft des schweizerischen Mittellandes [Pellet analysis in a population of the Little Owl Athene noctua in an intensively cultivated landscape (Grosses Moss) in Switzerland]. - Ornithologische Beobachter 100: 117-126. (in German)

Schmidt, E. 1967. Bagolyköpet vizsgálatok [Owl pellet analyses]. - A Magyar Madártani Intézet kiadványa, Budapest (in Hungarian)

Schmidt, E. 1998. Kuvik [Little Owl]. - In: Haraszthy, L. (ed.) Magyarország madarai [Birds of Hungary]. Mezőgazda Kiadó, Budapest, pp. 218-219. (in Hungarian)

Schönn, S., Scherzinger, W., Exo, K. M. \& Ille, R. 1991. Der Steinkauz [Little Owl]. - Die Neue Brehm-Bücherei, Vol. 606., A. Ziemsen Verlag, Wittenberg Lutherstadt, Germany (in German)

Shao, M. \& Liu, N. 2008. The diet of the Little Owl (Athene noctua) in the desert habitats of Northwestern China. - Journal of Raptor Research 42(1): 61-64. DOI: 10.3356/JRR-05-17.1

Shehab, A., Daoud, A., Kock, D. \& Amr, Z. 2004. Small mammals recovered from owl pellets from Syria (Mammalia: Chiroptera, Rodentia). - Zoology in the Middle East 33(1): 27-42. DOI: 10.1080/09397140. 2004.10638061

Simeonov, S. D. 1983. New data on the diet of the Little Owl (Athene noctua) in Bulgaria. - Ecology Sofia 11: 53-60.

Sunde, P., Thorup, K., Jacobsen, L. B., Holsegard-Rasmussen, M. H., Ottessen, N., Svenne, S. \& Rahbek, C. 2009. Spatial behaviour of Little Owls (Athene noctua) in a declining low-density population in Denmark. Journal of Ornithology 150: 537-548. DOI: 10.1007/s10336-009-0378-2

Szép, T. \& Nagy, K. 2006. Status of natural values in Hungary at the joining to the EU on the base of common bird monitoring (MMM) program of the MME for the 1999-2005 period. - Természetvédelmi Közlemények 12: 5-16.

Szép, T., Nagy, K., Nagy, Zs. \& Halmos, G. 2012. Population trends of common breeding and wintering birds in Hungary, decline of long-distance migrant and farmland birds during 1999-2012. - Ornis Hungarica 20(2): 13-63. DOI: 10.2478/orhu-2013-0007

Thorup, K., Sunde, P., Jacobsen, L. B. \& Rahbek, C. 2010. Breeding season food limitation drives population decline of Little Owl Athene noctua in Denmark. - Ibis 152: 803-814. DOI: 10.1111/j.1474-919X.2010.0 1046.x

Tomé, R., Catry, P., Bloise, C. \& Korpimäki, E. 2008. Breeding density and success, and diet composition of Little Owls Athene noctua in steppe-like habitats in Portugal. - Ornis Fennica 85: 22-32.

Tomialojc, L. \& Stawarczyk, T. 2003. The avifauna of Poland - distribution, numbers and trends. - PTPP pro Natura, Wroclaw (in Polish)

Topál, Gy. 1969. Denevérek - Chiroptera. - Magyarország Állatvilága (Fauna Hungariae) 22(2): 1-65. (in Hungarian)

Tryjanowski, P., Hartel, T., Báldi, A., Szymański, P., Tobolka, M., Herzon, I., Goławski, A., Konvicka, M., Hromada, M., Jerzak, L., Kujawa, K., Lenda, M., Orłowski, G., Panek, M., Skórka, P., Sparks, T. H., Wuczyński, A. \& Zmihorski, M. 2011. Conservation of farmland birds faces different challenges in Western and CentralEastern Europe. - Acta Ornithologica 46: 1-12. DOI: 10.3161/000164511X589857

Ujhelyi, P. 1989. A magyarországi vadonélő emlősállatok határozója [Identification of wild mammals in Hungary]. - Magyar Madártani Egyesület, Budapest (in Hungarian) 
Uttendörfer, O. 1939. Die Ernährung der deutschen Raubvögel und Eulen und ihre Bedeutung in der heimischen Natur [The diet of German birds of prey and owls and their importance in the nature]. - Neumann-Neudamm, Berlin (in German)

Van Nieuwenhuyse, D., Génot, J. \& Johnson, D. 2008. The Little Owl: Conservation, Ecology and Behavior of Athene noctua. - Cambridge, New York, Cambridge University Press

Voloscuk, I. 1999. The National Parks and Biosphere Reserves in Carpathians. The Last Nature Paradises. ACANAP Tatranska Lomnica, Slovak Republic, pp. 186-188., 190-192.

Zerunian, S., Franzini, G. \& Sciscione, L. 1982. Little Owls and their prey in Mediterranean habitat. - Bolletino di Zoologia 49: 195-206.

Zmihorski, M., Altenburg-Bacia, D., Romanowski, J., Kowalski, M. \& Osojca, G. 2006. Long-term decline of Little Owl (Athene noctua Scop., 1769) in central Poland. - Polish Journal of Ecology 54: 321-324.

Zmihorski, M., Romanowski, J. \& Osojca, G. 2009. Habitat preferences of a declining population of the Little Owl, Athene noctua in Central Poland. - Folia Zoologica 58: 207-215.

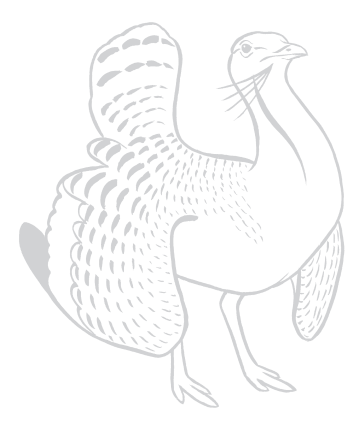

